\title{
Assessing Workplace Bullying: Spanish Validation of a Reduced Version of the Negative Acts Questionnaire
}

\author{
Bernardo Moreno Jiménez¹, Alfredo Rodríguez Muñoz ${ }^{1}$, Marino Martínez Gamarra², \\ and Macarena Gálvez Herrer ${ }^{1}$ \\ ${ }^{1}$ Universidad Autónoma de Madrid \\ ${ }^{2}$ Universidad de Zaragoza
}

\begin{abstract}
The aim of the present study was to validate a reduced Spanish version of the Negative Acts Questionnaire (NAQ; Einarsen \& Raknes, 1997). This instrument, which has been widely used in various studies, was developed to measure workplace bullying. Two samples, the first comprising 352 employees from 11 organizations, and the second comprising victims of bullying who were recruited from 15 Spanish associations against bullying, participated in the study. Exploratory factor analysis conducted with the data from the first sample revealed a two-factor solution that accounted for $63.3 \%$ of the total variance. The data from the second sample were used for confirmatory factor analyses to compare three structure models of the NAQ (one factor, two independent factors, and two correlated factors). The results indicate that the correlated twofactor model provided the best fit to the data $\left(\chi^{2} / \mathrm{df}=2.1, \mathrm{CFI}=.93, \mathrm{GFI}=.95, \mathrm{RMR}=.04, \mathrm{RMSEA}=.06\right.$, AIC $=215.4$ ). Reliability analysis showed that this 14-item Spanish version had high internal consistency. Significant correlations between the NAQ and its dimensions and diverse health and perceived stress scales were found, which provided evidence of construct validity. Taken conjointly, the results of this study support the use of the Spanish version of the reduced NAQ in future research.

Keywords: workplace bullying, assessment, Negative Acts Questionnaire, occupational health, validation
\end{abstract}

\begin{abstract}
El objetivo del presente estudio consiste en la validación española de una versión reducida del Negative Acts Questionnaire (NAQ; Einarsen \& Raknes, 1997). Este instrumento, que ha sido ampliamente utilizado en diferentes estudios, se desarrolló para la evaluación del acoso psicológico en el trabajo. Se emplearon dos muestras en el estudio. La primera estaba compuesta por 352 trabajadores de 11 organizaciones. La segunda muestra consistió en victimas de acoso psicológico, contactadas a través de 15 asociaciones españolas contra el acoso. El análisis factorial exploratorio, realizado con los datos de la primera muestra, mostró una solución de dos factores, que explica el 63,3\% de la varianza total. Los datos de la segunda muestra se utilizaron para realizar análisis factoriales confirmatorios con el objetivo de comparar tres modelos diferentes de la estructura del NAQ (un factor, dos factores independientes y dos factores correlacionados). Los resultados indican que el modelo de dos factores correlacionados es el que mejor se ajusta a los datos $\left(\chi^{2} / \mathrm{df}=2,1, \mathrm{CFI}=0,93, \mathrm{GFI}=0,95, \mathrm{RMR}=0,04, \mathrm{RMSEA}=0,06, \mathrm{AIC}=215,4\right)$. El análisis de la fiabilidad de la escala señaló que esta versión española de 14 ítems posee una elevada consistencia interna. Se encontraron correlaciones significativas entre el NAQ y sus dimensiones y distintas escalas de salud y el estrés percibido, lo que proporciona apoyo sobre su validez de constructo. De forma conjunta, los resultados de este estudio apoyan el uso de la versión española del NAQ reducido en futuras investigaciones.

Palabras clave: acoso psicológico en el trabajo, evaluación, Negative Acts Questionnaire, salud laboral, validación
\end{abstract}

Acknowledgements: This work was subsidized by the Fundación para la Prevención de los Riesgos Laborales (Foundation for the Prevention of Occupational Risks) and a predoctoral scholarship from the Universidad Autónoma de Madrid.

Correspondence concerning this article should be addressed to Bernardo Moreno Jiménez, Dpto. Psicología Biológica y Salud, Facultad de Psicología, Universidad Autónoma de Madrid, Ctra. Colmenar Viejo, km. 15, 28049 - Madrid (Spain). Phone: 91.4975185 / 91.4975225. E-mail: bernardo.moreno@uam.es

Translation: Virginia Navascués Howard 
Attention and research on the topic of workplace bullying has greatly increased in the last few years (Einarsen, Raknes, \& Matthiesen, 1994; Leymann, 1990a). The phenomenon has been studied under various terms, such as mobbing (Leymann, 1996), workplace bullying (Hoel, Cooper, \& Faragher, 2001), harassment (Björkqvist, Österman, \& HjeltBäck, 1994), emotional abuse (Keashly, 1998), victimization (Einarsen \& Raknes, 1997), and psychological terror (Leymann, 1990a). Despite the variety of terms, there is currently some consensus to conceptually delimit the phenomenon of bullying. Workplace bullying is defined as:

"Bullying at work means harassing, offending, socially excluding someone or negatively affecting someone's work tasks. In order for the label bullying (or mobbing) to be applied to a particular activity, interaction, or process, it has to occur repeatedly and regularly (e.g., weekly) and over a period of time (e.g., about six months). Bullying is an escalating process in the course of which the person confronted ends up in an inferior position and becomes the target of systematic negative social acts. A conflict cannot be called bullying if the incident is an isolated event or if two parties of approximately equal 'strength' are in conflict" (Einarsen, Hoel, Zapf, \& Cooper, 2003, p. 15).

From the time of Brodsky's (1976) and Leymann's (1990a) initial formulation of mobbing, one of the major concerns was how to assess the phenomenon. Initially, the first measures of workplace bullying were clinical observations, focusing on the facts and their consequences. Within this qualitative perspective, various techniques were developed. These include diary studies (Gross, 2002), case studies (Matthiesen, Aasen, Holst, \& Einarsen, 2003), and focalized discussion groups (Liefooghe \& Olafsson, 1999). As noted by Cowie, Naylor, and Rivers (2002), the use of questionnaires is very extended, because subjective perception is one of nuclear elements of this phenomenon. One of the most frequently used instruments is the Leymann Inventory of Psychological Terror (LIPT; Leymann, 1990b), in its different versions. The questionnaire has 45 or 46 items in the revised version that measure various bullying behaviors. The LIPT has been factorized many times (González de Rivera \& Rodríguez-Abuín, 2003; Leymann; Niedl, 1995). The most frequent factors revealed by the analyses are: social isolation, frequent task changes, violence or threats of violence, attacks at the person's integrity, and direct or indirect criticism. Doubtless, the LIPT facilitated systematic investigation of the theory, as it analyzed and summed up the behaviors that reflect bullying at work, so that it ceased to be a work problem that was difficult to objectify and define, an "abstract" problem, and became a problem divided into the behaviors that comprise it.

Currently, one of the most frequently used questionnaires, which has taken the place of the LIPT, is the Negative Acts Questionnaire (NAQ) developed by Einarsen and Raknes (1997). In the initial version, the authors proposed 29 items, which they later reduced to 22 items with a 5-point Likert- type response format ranging from 1 (never) to 5 (daily). The NAQ measures the frequency of exposure to various negative acts and behaviors that can be considered typical of bullying during the past six months. Two clearly differentiated components or dimensions have been identified: a component related to personal bullying behaviors, and a component of work-related bullying behaviors (Einarsen \& Hoel, 2001). Other studies have found three (Einarsen \& Raknes, 1997) and even four factors (Niedl, 1995), although the above-mentioned dimensions seem fairly stable. The internal consistency of the NAQ ranges between .87 and .93 (Einarsen, Raknes, Matthiesen, \& Hellesøy, 1996; Einarsen \& Raknes; Hoel et al., 2001). Correlations have been found with job satisfaction $(r=-.24$ to -.44$)$, psychological health $(r=-.31$ to -.52$)$, and psychosomatic complaints $(r=.32)$.

Various assessment instruments have been designed as alternatives to the NAQ, with a much reduced application field, so that knowledge of their scope and validity is very limited. The Work Harassment Scale (WHS), developed by Björkqvist et al. (1994), was designed to study bullying in the university population. This 24-item questionnaire, with a Likert-type response format (ranging from 0 to 4), has an internal consistency of .95 . The response method measures the frequency of bullying behaviors in the past six months. Alternatively, Einarsen et al. (1994) developed the Bergen Bullying Index, which is prior to the NAQ. This index has 5 items with a 4-point Likert-type response format and high internal consistency (.86). Rospenda and Richman (2004) developed a 29-item scale of harassment at work, the "Generalized Workplace Harassment Questionnaire". By means of factor analysis, the authors found four dimensions: covert hostility, verbal hostility, physical hostility, and manipulation.

In Spain, several instruments to measure bullying have been designed, such as the Cisneros barometer (Fidalgo \& Piñuel, 2004), or the "Cuestionario de Acoso Psicológico en el Trabajo" ([Bullying at Work Questionnaire] CAPT; Moreno-Jiménez, Rodríguez-Muñoz, Garrosa, \& Morante, 2005). We decided to adapt the NAQ because it is currently the most extensively used instrument, and this would facilitate comparative and cross-cultural studies. The NAQ has been frequently administered in many sectors and countries, among them Austria (Niedl, 1995), Australia (O'Farell, 2006), Belgium (Notelaers, Einarsen, De Witte, \& Vermunt, 2006), China (McCormack \& Casimir, 2006), Denmark (Mikkelsen \& Einarsen, 2001), the United States (Lutgen-Sandvik, Tracy, \& Alberts, 2004), Finland (Salin, 2001), the United Kingdom (Hoel et al., 2001), Italy (Giorgi, Matthiesen, \& Einarsen, 2006), Lithuania (Malinauskiene, 2004), Norway (Einarsen \& Raknes, 1997), and Portugal (Araujo, McIntyre, \& McIntyre, 2004). However, despite the fact that the NAQ is the most frequently used questionnaire to assess bullying at work, to our knowledge, there are no publications about its 
validation in Spain, either in its complete format or in a reduced version. Therefore, the purpose of this work is to analyze: (a) the psychometric properties of a reduced version of the NAQ in Spanish, selecting the most suitable items for the Spanish context; (b) its factor structure by means of exploratory and confirmatory factor analysis; and (c) its internal consistency and construct validity in the Spanish population.

\section{Method}

\section{Participants}

In order to validate the instrument, two samples were used. The first comprised 352 professionals from the corrugated cardboard sector, of whom 296 (86.3\%) were men. Their mean age was 36.02 years $(S D=10.27$, range $=17-63)$, whereas the mean work duration with the company was 10.90 years $(S D=10.33$, range $=1-46)$. Most of them (79.8\%) had a stable partner. Practically one half $(47.2 \%)$ had secondary education, whereas $42.5 \%$ had only completed primary education. Data were collected from 11 different companies of the sector. After obtaining approval for the project from the company supervisor, the research coordinator sent the assessment battery to the collaborating organizations. The questionnaires were handed out randomly to the employees, guaranteeing the confidentiality and anonymity of the data. Specifically, 400 protocols were sent out, and $352(88 \%)$ were returned.

The second sample comprised people who had requested assistance or help from some association or platform against bullying. According to the definition of workplace bullying, all of them considered themselves to be victims of bullying and they met the temporal criteria that are taken into account to judge a situation as bullying (Einarsen, 2000). The sample was made up of a total of 183 people, $46.4 \%$ were women, with a mean age of 39.58 years $(S D=7.85)$ and mean work experience of 15.17 years $(S D=9.07)$. Their educational level was mostly high school $(49.2 \%)$, whereas $41.5 \%$ had higher studies. Another interesting fact is that $45.9 \%$ of the participants indicated they were unemployed as a direct result of the bullying suffered, whereas $54.1 \%$ stated they had been in the bullying situation for over two years. All the people from this group had been systematically exposed to bullying strategies. Access to the sample of bullying victims was gained through 15 associations and platforms against bullying, distributed in 10 autonomous communities of the national territory. By means of a telephone interview, we explained the purpose of the study and gave instructions on how to complete the questionnaire to the representative of the association. Specifically, we sent 350 protocols, and $202(57.7 \%)$ were returned. Nineteen individuals who did not meet the above-mentioned criteria were excluded from the study.

\section{Instruments}

Negative Acts Questionnaire (NAQ; (Einarsen et al., 1994; Einarsen \& Raknes, 1997). A reduced version of the NAQ was used to assess workplace bullying. This scale reflects typical bullying behaviors, and the participants should respond to what degree they have suffered such behaviors during the last six months, on a 5-point Likert type rating scale, ranging from 1 (never) to 5 (daily). The original questionnaire was made up of 22 items, each one drawn up behaviorally. After responding to these items, a definition of bullying is presented and participants are requested to indicate whether they consider themselves victims of bullying according to the definition. The scale has shown high reliability and validity in previous studies (Einarsen et al., 1996; Einarsen \& Raknes, 1997; Hoel et al., 2001).

The following scales were also used to appraise construct validity:

The Shirom-Melamed Burnout Measure (SMBM; Melamed et al., 1999). This 12-item questionnaire evaluates three burnout dimensions: physical fatigue (4 items, e.g., "I feel physically drained"), emotional exhaustion (4 items, e.., "I feel emotionally burned out at work"), and cognitive weariness (4 items, e.g., "I have difficulty thinking about complex things"). Responses are rated on a 7-point Likert scale ranging from 1 (never) to 7 (always). In the present study, reliability (Cronbach's alpha) was .87, .79, and .83 for physical, emotional, and cognitive exhaustion, respectively.

We also employed the Spanish adaptation (Remor, 2006) of the Perceived Stress Scale (Cohen, Kamarck, \& Mermelstein, 1983). We used a reduced 8-item version (e.g., "In the last month, how often have you felt nervous or stressed?"), with a reliability coefficient of .85. Responses were rated on a 5-point Likert-type scale, ranging from 0 (never) to 4 (very frequently), which measures the level of perceived stress during the past month.

The Spanish validation (González, Moreno-Jiménez, Garrosa, \& López, 2005) of the Swedish Occupational Fatigue Inventory (Ahsberg, Gamberale, \& Kjellberg, 1997) was also used. This inventory has 25 items. Although the original version has five dimensions, in this study, we did not use the scale of physical exertion because this is already assessed in the above-mentioned questionnaires. The remaining scales, each one made up of 5 items are: lack of energy $(\alpha=.90)$, physical discomfort $(\alpha=.92)$, lack of motivation $(\alpha=.86)$, and sleepiness $(\alpha=.90)$. The response options range between 0 (not at all) and 10 (very much), and respondents should indicate to what degree they felt the symptoms at the end of their working day.

\section{Procedure}

The validation of the NAQ was carried out following the established requirements of the International Test Commission (ITC) (Hambleton, 1994; Van de Vijver \& Hambleton, 1996). 
The first phase of the process was to translate the NAQ into Spanish. This was carried out by a research team of experts in the subject. As some of the bullying behaviors have important cultural weight, we selected the items that seemed most suitable for the Spanish context. Thus, a reduced version of 14 items was created. Subsequently, a discussion group of three experts analyzed the formulation of the translated items and they redrafted some of them according to agreedon criteria. Then, the instrument was back-translated into English and the equivalence of both versions was determined (Brislin, 1970). Once the instrument had been translated, it was administered to the above-mentioned groups, after obtaining the participants' informed consent. The work was carried out within the framework of a more extensive research project about bullying and health, which was approved by the Ethics Committee for research in the Autonomous University of Madrid.

\section{Results}

\section{Exploratory Factor Analysis}

Factor validity of the questionnaire was evaluated first by exploratory factor analysis (EFA), using the sample of 352 employees. Following the recommendations of Dziubna and Shirkey (1974), before the analysis, we explored the psychometric adequacy of the items. Bartlett's (1950) sphericity test indicated that the items were dependent $(\mathrm{p}<$ .0001), whereas the Kaiser-Meyer-Olkin (1970) index was higher than the recommended value of $.50(K M O=.908)$. Therefore, the data showed good sample adequacy and suitable correlations of the items, which indicates they were appropriate for factor analysis.

As we expected the factors to be related, factor analysis was performed using principle components and oblique rotation (oblimin Kaiser). We applied the Kaiser criterion (Eigenvalue higher than 1) to extract the number of factors and, to assign the items to the factors, we considered factor loadings equal to or higher than .40. (Cliff \& Hamburger, 1967). Cattell's (1966) scree test or sedimentation test clearly showed a two-factor test structure, which accounted for $63.3 \%$ of the total variance (see Table 1).

The interpretability of the factor structures obtained suggested considering a two-factor structure as provisionally viable. Factor 1 comprised items 1, 2, 3, 9, 10, 11, 12, and 13, which assess work-related bullying behaviors. Factor 2 grouped items $4,5,6,7,8$, and 14 , which evaluates bullying behaviors involving attacks aimed at a person's private and personal life. The scale with the highest factor loading was work-related bullying, which accounted for $44.25 \%$ of the total variance of the questionnaire, whereas the personal bullying factor explained $19.13 \%$. Moreover, as can be seen in Table 1, all the items of the scale presented high factor loadings, ranging between .47 and .82 .
Table 1

Matrix of Factor Loadings and Communalities of each Item $(N=352)$

\begin{tabular}{cccc}
\hline Items & Communalities & $\begin{array}{c}\text { Work-related } \\
\text { bullying }\end{array}$ & $\begin{array}{c}\text { Personal } \\
\text { bullying }\end{array}$ \\
\hline 1 & .55 & $\mathbf{. 7 6}$ & .34 \\
2 & .61 & $\mathbf{. 6 0}$ & .40 \\
3 & .34 & $\mathbf{. 6 1}$ & .23 \\
9 & .46 & $\mathbf{. 4 8}$ & .30 \\
10 & .60 & $\mathbf{. 7 2}$ & .25 \\
11 & .54 & $\mathbf{. 6 8}$ & .22 \\
12 & .55 & $\mathbf{. 7 0}$ & .20 \\
13 & .59 & $\mathbf{. 8 1}$ & .31 \\
4 & .58 & .35 & $\mathbf{. 4 9}$ \\
5 & .57 & .38 & $\mathbf{. 4 7}$ \\
6 & .62 & .40 & $\mathbf{. 7 5}$ \\
7 & .61 & .28 & $\mathbf{. 6 6}$ \\
8 & .62 & .34 & $\mathbf{. 8 2}$ \\
14 & .50 & .25 & $\mathbf{. 7 6}$ \\
\hline
\end{tabular}

Note: Boldface indicates the items belonging to the factor.

\section{Confirmatory Factor Analysis}

Confirmatory factor analysis (CFA) of the items was carried out to ratify the model obtained in the exploratory analysis. To perform CFA, we used the sample of 183 victims of workplace bullying. We used the maximum likelihood method to analyze the correlation matrix. The analyses were performed with the structural equations program AMOS 5.0. (Arbuckle, 2003). Three different models were tested. Model 1 was proposed as the null hypothesis, which postulated a single factor on which all the items load. Model 2 postulated a two-factor structure with independent, uncorrelated factors. Model 3 proposed a structure of two correlated factors.

Goodness of fit of the proposed models was assessed by means of diverse fit indicators. Specifically, we used chi-squared divided by the degrees of freedom $\left(\chi^{2} / d f\right)$, the root mean square residual (RMSR,), and the root mean square error of approximation (RMSEA). Other relative fit indicators used were the goodness-of-fit index (GFI), the comparative fit index (CFI), and Akaikes' information criterion (AIC). These indexes are among the most frequently used, as they are less affected by sample size (García, Gallo, \& Miranda, 1998). For a fit to be considered good, CFI and GFI values should be higher than .90 (the higher the value, the better the fit). On the other hand, the RMSEA value should be lower then .08 for an acceptable fit (Browne \& Cudeck, 1993) or near .05 for a good fit (Byrne, 2001). Regarding the interpretation of the quotient $\chi^{2} / d f$, a value of 4 is considered reasonable fit, whereas values close to 2 are 
considered very good fit (Brooke, Russell, \& Price, 1988). Concerning AIC, it is considered that a lower value indicates a better fit of the model (Akaike, 1987). The goodness-of-fit indexes of the empirically contrasted model are presented in Table 2.

The results of the diverse goodness-of-fit indexes obtained reveal that Model 3, the correlated two-factor model, provided the best fit to the data. It can be observed that the values of CFI and GFI are higher than the recommended value of 90 (Byrne, 2001), whereas the values of RMR and RMSEA are close to or lower than .05. The AIC for Model 3 is notably lower than for the other two models. It appears, then, that the data empirically support the validity of the two-factor structure of the reduced version of the NAQ.

\section{Reliability Analysis}

The reliability of the two dimensions of the questionnaire was also examined by calculating its internal consistency with Cronbach's alpha, obtained separately for the bullying victims and the employees. Table 3 presents the values of internal consistency obtained, both for each subscale and for the global bullying score. As can be seen, all the values are higher than the recommended value of .70 (Nunnally \& Berstein, 1994). The global reliability coefficient for the scale was .85 and .89 , for the group of victims and employees, respectively. The means and correlations of each scale dimension are also displayed.

\section{Construct Validity}

Construct validity was studied by means of analysis of the correlations between the scale dimensions and with other, theoretically related, constructs. This was calculated with the sample of employees $(N=352)$. As observed in Table 4 , these analyses indicate that, as expected, bullying and its dimensions are positively correlated with health problems and perceived stress. The highest correlations are reached with emotional exhaustion, lack of energy, and physical discomfort (see Table 4), and the highest correlation of all was between perceived stress and the global bullying score $(r=.62, p<.01)$.

Table 2

Goodness-of-Fit Indexes of each one of the Proposed Models $(N=183)$

\begin{tabular}{lcccccc}
\hline Factor Model & $\chi^{2} / d f$ & CFI & GFI & RMR & RMSEA & AIC \\
\hline 1. One factor & 4.31 & .79 & .87 & .09 & .12 & 390.4 \\
2. Two independent factors & 3.70 & .83 & .89 & .08 & .09 & 310.9 \\
3. Two correlated factors & 2.10 & .93 & .95 & .04 & .06 & 215.4 \\
\hline
\end{tabular}

Note. $\chi^{2} / d f$ chi-square /degrees of freedom; CFI = Comparative fit index; GFI = Goodness of fit index; RMR = Root mean square residual; RMSEA = Root mean square error of approximation; AIC $=$ Akaikes information criterion.

All the $p$ values were statistically significant at the level of $p<.001$.

Table 3

Means, Standard Deviations, Reliability (Cronbach's alpha) and Correlations between the Total Score and the Dimensions of the NAQ for both Samples (Victims and Employees)

\begin{tabular}{|c|c|c|c|c|c|}
\hline NAQ & $M$ & $S D$ & $\alpha$ & 2 & 3 \\
\hline \multicolumn{6}{|c|}{ 1. Work-related bullying } \\
\hline Victims & 3.41 & .75 & .79 & $.67 * *$ & $.80 * *$ \\
\hline Employees & 1.70 & .79 & .84 & $.79 * *$ & $.86^{* *}$ \\
\hline \multicolumn{6}{|l|}{ 2. Personal bullying } \\
\hline Victims & 3.22 & .85 & .84 & & $.76^{* *}$ \\
\hline Employees & 1.33 & .55 & .82 & & $.81 * *$ \\
\hline \multicolumn{6}{|c|}{ 3. Global bullying score } \\
\hline Victims & 3.33 & .68 & .85 & & \\
\hline Employees & 1.54 & .64 & .89 & & \\
\hline
\end{tabular}

$* * p<.01$. 
Table 4

Pearson's Correlations among the NAQ Dimensions and other Constructs $(N=352)$

\begin{tabular}{|c|c|c|c|}
\hline & Work-related bullying & Personal bullying & Global bullying score \\
\hline \multicolumn{4}{|c|}{ Swedish Occupational Fatigue Inventory } \\
\hline Lack of energy & .52 & .39 & .50 \\
\hline Physical discomfort & .51 & .36 & .49 \\
\hline Lack of motivation & .47 & .35 & .47 \\
\hline Sleepiness & .36 & .31 & .38 \\
\hline \multicolumn{4}{|c|}{ Shirom-Melamed Burnout Measure } \\
\hline Emotional exhaustion & .58 & .43 & .57 \\
\hline Physical fatigue & .39 & .29 & .36 \\
\hline Cognitive weariness & .43 & .34 & .42 \\
\hline \multicolumn{4}{|l|}{ Perceived Stress Scale } \\
\hline Perceived stress & .61 & .55 & .62 \\
\hline
\end{tabular}

Note. The values of all correlations were statistically significant at the level of $p<.01$.

\section{Discussion}

The principal goal of this work was the adaptation in Spanish of a reduced version of the Negative Acts Questionnaire and the study of its internal consistency and factor and construct validity. The analyses performed indicate that this version of the NAQ has satisfactory psychometric properties.

The exploratory factor analysis showed that the twofactor structure was the most adequate, accounting for a large percentage of the total variance, even more than that obtained in previous investigations. Confirmatory factor analysis allowed us to determine that the correlated twofactor model provided the best fit to the data. This complements the literature, because this analysis technique has hardly been used to confirm the dimensionality of the NAQ. The results of this study are in accordance with previous research. Einarsen and Hoel (2001) found two factors: work-related bullying behaviors and attacks on people's private and personal life, with a reliability of .89 . In the Italian validation of the NAQ (Giorgi et al., 2006), the 22-item version was reduced to 17 items, the same two factors emerged, accounting for $50.3 \%$ of the variance and with a reliability similar to the one found in the present study (.90). In contrast, Einarsen and Raknes (1997), using principle component factor analysis and varimax rotation, obtained three factors: social exclusion, work-related harassment, and personal attacks. The analyses performed by Niedl (1995) found four factors: personal harassment behaviors, social isolation, work-related measures, and physical violence. Despite the differences found in the diverse studies, some of the factors are shared by the different samples, and these correspond to the factors found in our investigation. The dimensions of work-related bullying and bullying behaviors aimed at people's personal life emerge systematically. Moreover, it is logical that the diverse studies find differences in the types of harassment, depending on the sample and the setting, as bullying and harassment behaviors are dynamic factors that change (Leymann, 1990a).

Moreover, the scale presented has very good internal consistency, comparable to that of the original version and within the range obtained in other investigations (Einarsen et al., 1996; Einarsen \& Raknes, 1997; Hoel et al., 2001). All the scales exceed the recommended minimum criterion of .70 (Nunally \& Berstein, 1994).

With regard to construct validity of the NAQ, as expected, significant correlations were found among the different types of bullying and diverse health measures, such as emotional exhaustion and lack of energy, and perceived stress. Einarsen, Matthiesen, and Skogstad, (1998) had previously reported an association between bullying and burnout in a sample of nurses; moreover Quine (2001) found an association between low levels of job satisfaction and workplace bullying. On the other hand, Giorgi et al. (2006) found that harassment is positively related to other related constructs, such as, for example, incivility behaviors at work.

Summing up, the results found indicate that the validation of the NAQ in Spanish, in a reduced 14-item version, has satisfactory psychometric properties, so it can be considered a valid and reliable measure to assess workplace bullying. However, some limitations of the present study and questionnaire should be pointed out. The main limitation is that the 22 items of the original questionnaire were reduced to 14 items based on the consensus of a group of experts, but not on empirical statistical criteria. Reducing the instrument may facilitate its administration but, at the same time, perhaps not all the bullying behaviors are reflected on the list of the questionnaire. On the other hand, we think it 
is necessary to extend the sample to include other groups and occupations in order to confirm the scale structure. Moreover, we think it is pertinent to explore the temporal stability, and to complement the self-reported measures of the NAQ with other assessment methods, such as, for example, interviews. Likewise, future studies should control the possible effect of certain personality variables, for example, negative affect. Lastly, the authors of the questionnaire issue a warning that the NAQ is not a diagnostic instrument. Due to the need to discriminate whether or not a worker has been the victim of bullying, especially in legal cases, future investigations should develop studies with clinical referents so as to obtain diagnostic criteria, different from the currently established temporal criteria (Leymann, 1996).

\section{References}

Ahsberg, E., Gamberale, F., \& Kjellberg, A. (1997). Perceived quality of fatigue during different occupational tasks. Development of a questionnaire. International Journal of Industrial Ergonomics, 20, 121-135.

Akaike, H. (1987). Factor analysis and AIC. Psychometrika, 52, 317-332.

Araujo, S., McIntyre, S., \& McIntyre, T. (2004, June). Portuguese adaptation of the Negative Acts Questionnaire: Preliminary results. Work presented in the $4^{\text {th }}$ International Conference on Bullying and Harassment in the Workplace Bergen, Norway.

Arbuckle, J.L. (2003). Amos 5.0. Chicago, IL: SPSS.

Bartlett, M.S. (1950). Test of significance in factor analysis. British Journal of Psychology, 3, 77-85.

Björkqvist, K., Österman, K., \& Hjelt-Bäck, M. (1994). Aggression among university employees. Aggressive Behavior, 20, 173184.

Brislin, R.W. (1970). Back-translation for cross-cultural research. Journal of Cross-Cultural Psychology, 1, 185-216.

Brodsky, C.M. (1976). The harassed worker. Toronto: Lexington Books, DC Heath and Company.

Brooke, P.P., Jr., Russell, D.W., \& Price, J.L. (1988). Discriminant validation of measures of job satisfaction, job involvement, and organizational commitment. Journal of Applied Psychology, 73, 139-145.

Browne, M. W., \& Cudeck, R. (1993). Alternative ways of assessing model fit. In K.A. Bollen \& J.S. Long (Eds.), Testing structural equation models (pp. 136-162). Newbury Park, CA: Sage.

Byrne, B.M. (2001). Structural equation modeling with Amos: Basic concepts, applications and programming. Mahwah, NJ: Erlbaum.

Cattell, R.B. (1966). The meaning and strategic use of factor analysis. In R. Cattell (Ed.), Handbook of multivariate experimental psychology. Chicago: Rand McNally.

Cliff, N., \& Hamburger, C.D. (1967). The study of sampling errors in factor analysis by means of artificial experiments. Psychological Bulletin, 68, 430-445.
Cohen, S., Kamarck, T., \& Mermelstein, R. (1983). A global measure of perceived stress. Journal of Health and Social Behaviour, 24, 385-396.

Cowie, H., Naylor, P., \& Rivers, I. (2002). Measuring workplace bullying. Aggression and Violent Behavior, 7, 33-51.

Dziuban, C.D., \& Shirkey, E.C. (1974). When is a correlation appropriate for factor analysis? Some decision rules. Psychological Bulletin, 81, 358-361.

Einarsen, S. (2000). Harassment and bullying at work: A review of the Scandinavian approach. Aggression and Violent Behavior, 4, 379-401.

Einarsen, S., \& Hoel, H. (2001, May). The Negative Acts Questionnaire: Development, validation and revision of a measure of bullying at work. Work presented at the $10^{\text {th }}$ European Congress on Work and Organizational Psychology, Prague.

Einarsen, S., Hoel, H., Zapf, D., \& Cooper, C.L. (2003). The concept of bullying at work. The European tradition. In S. Einarsen, H. Hoel, D. Zapf, \& C.L. Cooper (Eds.), Bullying and emotional abuse in the workplace. International perspectives in research and practice (pp. 3-30). London: Taylor $\&$ Francis.

Einarsen, S., Matthiesen, S.B., \& Skogstad, A. (1998). Bullying, burnout and well-being among assistant nurses. Journal of Occupational Health and Safety - Australia and New Zealand, 14, 263-268.

Einarsen, S., \& Raknes, B.I. (1997). Harassment in the workplace and the victimization of men. Violence and Victims, 12, 247263.

Einarsen, S., Raknes, B.I., \& Matthiesen, S.B. (1994). Bullying and harassment at work and their relationships to work environment quality: An exploratory study. European Work and Organizational Psychology, 4, 381-401.

Einarsen, S., Raknes, B.I., Matthiesen, S.B., \& Hellesøy, O.H. (1996). Helsemessige aspekter ved mobbing i arbeidslivet. Modererende effekter av social støtte og personlighet (Bullying at work and its relationships with health complaints moderating effects of social support and personality). Nordisk Psykologi, 48, 116-137.

Fidalgo, A.M., \& Piñuel, I. (2004). La escala Cisneros como herramienta de valoración del mobbing. Psicothema, 16, 615624.

García, E., Gallo, P., \& Miranda, R. (1998). Bondad de ajuste en el análisis factorial confirmatorio. Psicothema, 10, 717-724.

Giorgi, G., Matthiesen, S.B., \& Einarsen, S. (2006, June). Italian validation of the Negative Acts Questionnaire. Work presented at the $5^{\text {th }}$ International Conference on Bullying and Harassment in the Workplace. Dublin, Ireland.

González, J.L., Moreno-Jiménez, B., Garrosa, E., \& López, A. (2005). Spanish version of the Swedish occupational fatigue inventory: Factorial replication, reliability and validation. International Journal of Industrial Ergonomics, 35, 737-746.

González de Rivera, J.L., \& Rodríguez-Abuín, M. (2003). Cuestionario de estrategias de acoso psicológico: el LIPT-60. Psiquis, 24, 59-66. 
Gross, C. (2002, September). Social conflicts and bullying at work: First results of a diary study. Work presented at the International Conference on Bullying and Harassment at work, London, UK.

Hambleton, R.K. (1994). Guidelines for adapting educational and psychological tests: A progress report. European Journal of Psychological Assessment, 10, 229-244.

Hoel, H., Cooper, C.L., \& Faragher, B. (2001). The experience of bullying at work in Great Britain: The impact of organisational status. European Journal of Work and Organisational Psychology, 10, 414-425.

Kaiser, H.F. (1970). A second generation little jiffy. Psychometrika, 35, 401-416.

Keashly, L. (1998). Emotional abuse in the workplace. Journal of Emotional Abuse, 1, 85-117.

Leymann, H. (1990a). Mobbing and psychological terror at workplaces. Violence and Victims, 5, 119-126.

Leymann, H. (1990b). Manual of the LIPT questionnaire for assessing the risk of psychological violence at work. Stockholm: Violen.

Leymann, H. (1996). The content and development of mobbing at work. European Journal of Work and Organizational Psychology, 5, 165-184.

Liefooghe, A., \& Olafsson, R. (1999). "Scientists" and "amateurs": Mapping the bullying domain. International Journal of Manpower, 20, 39-49.

Lutgen-Sandvik, P., Tracy, S. J., \& Alberts, J. K. (2004, June). Workplace bullying in the United States: Incidence, comparison to international research and an introduction of bullying "degree." Work presented at the $4^{\text {th }}$ International Conference on Bullying and Harassment in the Workplace, Bergen, Norway.

Malinauskiene, V. (2004, June). Bullying among teachers in Kaunas, Lithuania. Work presented at the $4^{\text {th }}$ International Conference on Bullying and Harassment in the Workplace, Bergen, Norway.

Matthiesen, S., Aasen, E., Holst, G., K., W., \& Einarsen, S. (2003). The escalation of conflict: A case study of bullying at work. International Journal of Management and Decision Making, 4, 96-112.

McCormack, D., \& Casimir, G. (2006, June). Workplace bullying behaviours among schoolteachers: An Australia-China comparison. Work presented at the $5^{\text {th }}$ International Conference on Bullying and Harassment in the Workplace. Dublin, Ireland.

Melamed, S., Ugarten, U., Shirom, A., Kahana, L., Lerman, Y., \& Froom, P. (1999). Chronic burnout, somatic arousal and elevated cortisol levels. Journal of Psychosomatic Research, 6, 591-598.
Mikkelsen. E.G., \& Einarsen, S. (2001). Bullying in Danish worklife: Prevalence and health correlates. European Journal of Work and Organisational Psychology, 10, 393-413.

Moreno-Jiménez, B., Rodríguez-Muñoz, A., Garrosa, E., \& Morante, M.E. (2005). Antecedentes organizacionales del acoso psicológico en el trabajo: un estudio exploratorio. Psicothema, 17, 627-632.

Niedl, K. (1995). Mobbing/bullying am Arbeitsplatz. Eine empirische Analyse zum Phänomen sowie $z u$ personalwirtschaftich relevanten Effekten von systematischen Feindligkeiten [Mobbing/bullying in the workplace: An empirical analysis of the phenomenon and of the effects of systematic hostilities relevant for human resource management]. Doctoral dissertation. Munich, Germany: Rainer Hampp Verlag.

Notelaers, G., Einarsen, S., De Witte, H., \& Vermunt, J. (2006). Measuring exposure to bullying at work: The validity and advantages of the latent class cluster approach. Work \& Stress, 20, 288-301.

Nunnally, J.C., \& Berstein, I.H. (1994). Psychometric theory (3 $3^{\text {rd }}$ ed.). New York: McGraw-Hill.

O'Farell, B. (2006, June). Forms of workplace bullying and its measurement: the Negative Acts Questionnaire-Revised in Australia. Work presented at the $5^{\text {th }}$ International Conference on Bullying and Harassment in the Workplace. Dublin, Ireland.

Quine, L. (2001). Workplace bullying in nurses. Journal of Health Psychology, 6, 73-84.

Remor, E. (2006). Psychometric properties of a European Spanish version of the perceived stress scale. The Spanish Journal of Psychology, 9, 86-93.

Rospenda, K.M., \& Richman, J.A. (2004). The factor structure of generalized workplace harassment. Violence and Victims, 19, 221-238.

Salin, D. (2001). Prevalence and forms of bullying among business professionals: A comparison of two different strategies for measuring bullying. European Journal of Work and Organizational Psychology, 10, 425-441.

Van de Vijver, F., \& Hambleton, R.K. (1996). Translating tests: Some practical guidelines. European Psychologist, 2, 89-99.

Received September, 20, 2006

Revision received January, 12, 2007 Accepted March 26, 2007 


\section{Appendix}

\section{Negative Acts Questionnaire (NAQ) [Spanish version]}

Las siguientes acciones son, con frecuencia, entendidas como ejemplos de comportamientos negativos en el trabajo. Por favor, rodee con un círculo el número que mejor corresponda con su experiencia durante los últimos seis meses:

$\begin{array}{ccccc}1 & 2 & 3 & 4 & 5 \\ \text { Nunca } & \text { De vez en cuando } & \text { Mensualmente } & \text { Semanalmente } & \text { Diariamente }\end{array}$

Durante los seis últimos meses, ¿con qué frecuencia ha sido víctima de los siguientes comportamientos negativos en su lugar de trabajo?

1. Me han restringido información que afecta a mi rendimiento

2. He sido ridiculizado en relación con mi trabajo

3. Me han ordenado tareas por debajo de mis competencias

4. Se han extendido chismes y rumores sobre mi

5. He sido ignorado, excluido o aislado físicamente

6. He sido víctima de insultos u ofensas en relación a mi forma de ser, mis actitudes o mi vida privada

7. He sido objeto de gritos o reacciones de cólera injustificada

8. He sido víctima de comportamientos intimidatorios como empujones, bloqueos o invasiones de mi espacio personal

9. Me han recordado constantemente cualquier error o fallo que he cometido

10. Mis opiniones y puntos de vista han sido ignorados

11. He sido controlado y/o vigilado en extremo

12. He recibido presiones para que no reclamase algo que por derecho me corresponde (baja por enfermedad, vacaciones, etc.)

13. He sido expuesto a una carga de trabajo imposible de llevar a cabo

14. He sido objeto de amenazas de violencia o abuso físico

El acoso psicológico consiste en continuadas actitudes hostiles, dirigidas de manera sistemática por uno o varios individuos contra otro, con el fin de desprestigiar, humillar, aislar y, en último término, provocar el abandono del puesto de trabajo. Usando esta definición, por favor señale si ha sido acosado psicológicamente en el trabajo durante los últimos seis meses

No

Sí, de vez en cuando

Sí, varias veces por semana

¿Cuándo comenzó el acoso psicológico?

Durante los últimos seis meses

Hace 1 o 2 años

\section{Sí, raramente}

Sí, varias veces al mes

Sí, prácticamente a diario

Acoso Laboral (Work-related bullying): Items 1, 2, 3, 9, 10, 11, 12 and 13. Acoso Personal (Personal bullying): Items 4, 5, 6, 7, 8 and 14. 